\title{
Pembentukkan Karakter Remaja Kota Padang Melalui Program Generasi Berencana Untuk Menghadapi Bonus Demografi 2030
}

Vitri Intan Sari. Junaidi Indrawadi

Program Studi Pendidikan Pancasila dan Kewarganegaraan

Universitas Negeri Padang

E-mail: intasarivitri@gmail.com

\section{ABSTRAK}

Indonesia adalah salah satu negara yang memiliki permasalahan dalam kependudukan. Jumlah penduduk yang tinggi mengakibatkan kurangnya wadah dalam upaya peningkatan sumber daya manusia. Oleh karena itu, Untuk merespon permasalahan tersebut Direktorat Bina Ketahanan Remaja Badan Kependudukan dan Keluarga Berencana Nasional (BKKBN) mengadakan sebuah program yang bernama "Generasi Berencana (GenRe)". Penelitian ini bertujuan untuk mengidentifikasi dan melihat keberhasilan pelaksanaan program GenRe dalam membantu merealisasikan UU RI Nomor 20 Tahun 2003 tentang Sistem Pendidikan Nasional khususnya pembentukkan karakter remaja di Kota Padang. Penelitian ini merupakan penelitian kualitatif metode deskriptif. Pemilihan informan menggunakan teknik purposive sampling yaitu 40 orang informan yang tersebar di 6 titik Kota Padang Provinsi Sumatera Barat. Program GenRe adalah program yang dikembangkan dalam rangka persiapan bonus demografi 2030 untuk membentuk tegar remaja yang kreatif, inovatif dan penuh perencanaan masa depan. Hasil penelitian menunjukkan (1) Program GenRe sejalan dengan filosofi hidup orang Minangkabau "Adat basandi sarak, sarak basandi kitabullah, sarak mangato, adat mamakai, alam takambang jadi guru". Melalui program ini dapat terlihat dengan jelas perpaduan antara aturan adat, agama, dan Negara dalam rangka membentuk karakter generasi muda, (2) Pembentukkan karakter remaja dilakukan melalui dua pendekatan yaitu secara langsung (sekolah) dan secara tidak langsung (orang tua). Namun, pembentukkan karakter remaja di Kota Padang melalui program GenRe belum terlaksana secara optimal karena tiga faktor (1) Operasional waktu, (2) Tenaga ahli (peran duta GenRe), (3) Pendanaan. Hasil penelitian ini sangat menarik menjadi bahan diskusi untuk melihat perkembangan pelaksanaan program GenRe sebagai solusi pemerintah dalam membantu permasalahan yang dialami remaja.

Kata Kunci: Remaja, Karakter, BKKBN, Bonus Demografi, Program GenRe

\section{ABSTRACT}

Indonesia is one country that has problem in population. The high population gives the lack of a container in an effort to increase human resources. Therefore, to respond to these problems the Directorate of Youth Resilience of the National Population and Family Planning Agency (BKKBN) held a program called "Generation of Planning (GenRe)". This study aims 
to identify and see the success of the implementation of the GenRe program in helping realize the Republic of Indonesia Law Number 20 of 2003 concerning the National Education System, especially the formation of youth characters in Padang. Thisstudy is a descriptive qualitative research method. The selection of informants used a purposive sampling technique, namely 40 informants spread across 6 points in Padang, West Sumatra. The GenRe Program is a program developed in preparation for the 2030 demographic bonus to form adolescents who are creative, innovative and full of future planning. The results showed (1) the GenRe Program was in line with the philosophy of life of the Minangkabau people "Adat basandi sarak, sarak basandi kitabullah, sarak mangato, adat mamakai, alam takambang jadi guru". Through this program it can be seen clearly the combination of the rules of adat, religion, and the state in order to shape the character of the younger generation, (2) The formation of adolescent character is done through two approaches namely directly (school) and indirectly (parents). However, the formation of adolescent characters in Padang through the GenRe program has not been implemented optimally because of three factors (1) Operational time, (2) Experts (the role of the Gen ambassador), (3) Funding. The results of this study are very interesting as material for discussion to see the development of the implementation of the GenRe program as a government solution in helping the problems experienced by adolescents.

Keywords : Youth, Character, BKKBN, Demographic Bonus, GenRe Program

\begin{tabular}{cc}
\hline Received: 2019-08-06 & Accepted: 2019-09-01 \\
\hline \hline
\end{tabular}

\section{PENDAHULUAN}

Karakter adalah nilai-nilai yang harus dimiliki suatu bangsa untuk bisa eksis dalam persaingan global (Purnomo, 2014). Sedangkan yang terjadi di Indonesia saat ini adalah krisis karakter sebagai cerminan dari kegagalan struktur sosial yang ada dalam menjalankan peran dan fungsinya. Struktur yang ada dalam masyarakat punya peranan dan tugas untuk menjaga nilai dan norma agar dapat menjadi pedoman masyarakat dalam bertindak. Indonesia memerlukan sumber daya manusia (SDM) baik dari sisi kuantitas maupun kualitas yang harus memadai sebagai pendukung utama dalam pembangunan bangsa. Namun selama ini kurangnya wadah bagi remaja untuk melakukan konseling dalam menyelesaikan permasalahan yang dialaminya mengakibatkan tidak terwujudnya tujuan bangsa untuk memiliki generasi penerus yang teruji secara kualitas. Sebagai generasi penerus bangsa seharusnya remaja melakukan apa yang menjadi tanggung jawab diusia mereka. Remaja yang mampu menyelesaikan pendidikannya dengan baik maupun menjadi bibit unggul dalam pembangunan nasional Negara, memiliki karir dalam pekerjaan yang baik, mampu merencanakan kehidupan berkeluarga, serta dapat berperan aktif dalam kehidupan bermasyarakat.

Remaja seperti itulah sesungguhnya yang diinginkan dan dibutuhkan oleh negara kita pada saat ini untuk menyambut bonus demografi tahun 2030 dalam menghadapi persaingan global. 
Sumber daya manusia saat ini banyak terkontaminasi oleh berbagai jenis kenakalan remaja khususnya di Kota Padang. kenakalan remaja di Kota Padang mulai mengkhawatirkan masyarakat, bahkan hampir setiap hari ada remaja yang tertangkap oleh Satpol PP Kota Padang dengan berbagai kasus prilaku menyimpang. Tahun 2017 Satpol PP Kota Padang sudah menangani dan melakukan penertiban terkait kasus kenakalan remaja sebanyak 746 kasus pelanggaran yang mengganggu ketertiban umum dan ketentraman masyarakat. kasus pelanggaran yang terjadi seperti bolos pada jam sekolah, tawuran antar pelajar, menghisap lem, dan beberapa kasus Penyakit Masyarakat (Pekat) yakni remaja suka nongkrong di kafe hiburan malam tanpa kartu Identitas diri, pasangan ilegal di penginapan dan Waria (ImpianNews, 2018)

Sehingga untuk mengatasi atau mengurangi permasalahan tersebut, pemerintah meluncurkan sebuah program bernama "Generasi Berencana" untuk merespon permasalahan remaja bersama dengan Badan Kependudukan dan Keluarga Berencana Nasional (BKKBN). Sejalan dengan penelitian yang telah dilakukan oleh Devi Yana Utami terkait program GenRe dalam rangka pembangunan manusia menuju pembangunan nasional berkualitas mengungkapkan bahwa program ini adalah upaya dalam pembangunan SDM sebagai bagian dari program pembangunan telah dilakukan pemerintah pada banyak aspek kehidupan masyarakat termasuk pembangunan SDM yang dilakukan oleh BKKBN melalui program Generasi Berencana (GenRe) yang
Volume 2 No. 42019

bertujuan untuk meningkatkan kualitas SDM pada tataran remaja agar kedepannya memiliki kemampuan untuk menjalani kehidupan berkualitas dan berdaya saing tinggi (Dwiyana, 2015).

Program GenRe ini terfokus pada pembinaan karakter remaja Indonesia menjadi remaja visioner. Mirisnya karakter saat ini membuat penulis tertarik untuk meneliti dan menggali lagi apa sebenarnya yang salah terkhusus dari remaja sebagai penerus dan harapan bangsa. Program GenRe ini memiliki dua pendekatan yaitu Pusat Informasi Konseling (PIK) jalur pendidikan secara langsung dan Bina Keluarga Remaja (BKR) jalur masyarakat secara tidak langsung. Seperti hasil penelitian dari Binti Maunah terkait dengan pembentukan karakter anak juga dapat dilakukan melalui dua strategi sama halnya dengan dua pendekatan program GenRe tersebut, yaitu internal sekolah dan eksternal sekolah. Strategi internal sekolah dapat dilakukan melalui empat pilar, yakni kegiatan proses belajar mengajar di kelas, kegiatan keseharian dalam bentuk budaya sekolah (school culture), kegiatan pembiasaan (habituation), kegiatan kokurikuler dan ekstrakurikuler. Strategi eksternal dapat dilakukan melalui keluarga dan masyarakat (Maunah, 2014).

Program GenRe yang dirancang oleh Pemerintah dibawah pengawasan dari BKKBN memiliki sebuah keunikan tersendiri, yaitu pelaksana dari kedua pendekatan program adalah remaja sehingga terciptanya suasana yang sesuai dengan usia remaja tersebut. Dalam pembentukkan karakter remaja Kota Padang melalui program Generasi Berencana (GenRe) 
ini bukanlah penelitian yang pertama dilakukan, akan tetapi sudah ada beberapa penelitian terdahulu terkait dengan tema ini. Sehingga itu dijadikan oleh peneliti sebagai referensi yang mengacu kepada penelitian selanjutnya dengan fokus dan objek yang berbeda. Dan ini juga dilakukan untuk mempermudah peneliti dalam memahami pelaksanaan program Generasi Berencana (GenRe) dibeberapa sekolah dan lingkungan masyarakat.

Penelitian terdahulu yang dijadikan acuan oleh penulis ialah hasil penelitian dari Fitriani Mediastuti terkait dengan adanya upaya untuk mengurangi perilaku berisiko pada remaja, yaitu melalui Pusat Informasi dan Konseling Remaja (PIK R) yang berbasis masyarakat. Pengelolaan PIK $\mathrm{R}$ berbasis masyarakat yang efektif membutuhkan support manajemen, pemberdayaan masyarakat, dan koordinasi dari berbagai stakeholder (Mediastuti \& Setyorini, 2014). Begitu juga dengan hasil penelitian dari Lilis Indah sari yang memaparkan adanya implementasi ekstrakurikuler Pusat Informasi dan Konseling Remaja (PIKR) dalam mengecah kenakalan remaja dilakukan melalui tiga kegiatan yaitu penyuluhan atau sosialisasi, konseling, dan membangun keakraban yang dikategorikan sangat baik dengan jumlah persentase sebesar 89,46\% (Indahsari \& Setyowati, 2015).

Dari hasil penelitian terdahulu dengan tema dan objek yang sama namun fokus penelitian yang berbeda jika dilihat dari hasil penelitian yang dilakukan oleh Mega Andriani tahun 2016 di BKKBN D.I Yogyakarta dalam upaya mengurangi masalah sosial yang tejadi pada remaja. Dan hasil penelitian yang dilakukan di
Kabupaten Berau, Provinsi Kalimantan Timur diketahui bahwa pengembangan Program Generasi Berencana (GenRe) belum berjalan maksimal hal ini dikarenakan tidak aktifnya generasi berencana. Selain itu pengembangan Program Generasi Berencana (GenRe) masih terkendala terbatasnya dana pelatihan dan dana kegiatan, dan kurangnya tenaga pengelola. Program yang sama, hanya saja subjek pengelolah dan cara pengelohan yang berbeda. Di Kota Padang saat ini masih belum terlihat dengan baik hasil dari program dan kegiatan ini. Pada kenyataannya dalam menjalankan tugas yang berkaitan dengan peran remaja untuk membantu dirinya dan teman sebaya dalam meminimalisir serta menyelesaikan setiap permasalahan yang dihadapi remaja tersebut belum berjalan dengan maksimal. Akses dan kualitas pengelolaan PIK $\mathrm{R}$ dan BKR masih relatif pasif beserta dengan tingkat kepedulian rendah menjadi permasalahan yang menghambat berjalannya program ini. seperti masih kurangnya sosialisasi dilingkungan masyarakat sehingga banyak yang belum mengetahui program generasi berencana ini.

Tujuan dari peneliti menulis artikel ini adalah untuk menjawab dan memberitahu kepada masyarakat bahwa ada solusi inovatif yang dimunculkan oleh pemerintah beserta instansi terkait dalam membantu menyelesaikan permasalahan remaja. Solusinya yaitu melalui peran generasi berencana yang terdiri dari remajaremaja pilihan yang telah diseleksi guna membantu pemerintah/instansi dalam melaksanakan programprogram keremajaan. Sehingga solusi ini menumbuhkan pelayanan yang 
benuasa dan bercita rasa remaja melalui pelaksanaan program GenRe. Serta untuk mengetahui dan melihat upaya dari Kantor Dinas Pemberdayaan Perempuan, Perlindungan Anak, Pengendalian Penduduk, dan Keluarga Berencana (DP3AP2KB) dalam mengembangkan program generasi berencana (GenRe) disetiap Kabupaten dan Kota dan juga untuk mengetahui bagaimana tanggapan masyarakat terhadap keberadaan Duta GenRe dan program GenRe tersebut.

\section{METODE PENELITIAN}

Penelitian ini merupakan jenis penelitian kualitatif metode deskriptif. Penelitian ini berlokasi di Kota Padang Provinsi Sumatera Barat dengan lima titik lokasi penelitian, antara lain Dinas Pemberdayaan Perempuan, Perlindungan Anak, Pengendalian Penduduk, dan Keluarga Berencana (DP3AP2KB) Kota Padang, PIK R Serasi SMPN 25 Padang (kategori tumbuh), PIK R Sabai Nan Aluih SMPN 11 Padang (kategori tegar model), kelompok BKR Anggrek Kec. Padang Selatan (kategori berkembang), kelompok BKR Kampung KB Sinar Gunung IV Kec. Padang Utara (kategori dasar). Teknik pemilihan informan yang digunakan peneliti ialah Purposive Sampling dengan 40 orang informan. Dan hasil penelitian ini akan di uji dengan teknik triangulasi.

\section{HASIL DAN PEMBAHASAN}

Dasar dari munculnya program yang digagas oleh Badan Kependudukan dan Keluarga Berencana Nasional (BKKBN) ini karena tingginya angka persentase kenakalan remaja. Khususnya di Kota Padang yang merupakan kategori
Kota Pendidikan dengan banyaknya sekolah-sekolah dan perguruan tinggi. Direktorat Bina Ketahanan Remaja (Dithanrem) Badan Kependudukan dan Keluarga Berencana Nasional (BKKBN) bersama dengan Dinas Pemberdayaan

Perempuan, Perlindungan Anak, Pengendalian Penduduk dan Keluarga Berencana (DP3AP2KB) sebagai pengawas utama setiap Kabupaten/Kota di Provinsi Sumatera Barat menjawab permasalahan terkait kenakalan remaja di Kota Padang dengan melucurkan sebuah program yang disebut "Generasi Berencana". Program ini dilaksanakan juga untuk mendukung dan mempertahankan adat istiadat dan budaya di Minang Kabau, sesuai dengan falsafah budaya minang yang berbunyi "Adat basandi sarak, sarak basandi kitabullah, sarak mangato, adat mamakai, alam takambang jadi guru". penggabungan adat dan agama yang menjadi dasar semangat hidup.

Akidah tauhid sebagai ajaran islam dipupuk mulai dari budi dalam tata pergaulan dirumah tangga dan ditengah masyaratakat. Demikialah masyarakat Minangkabau memaknai setiap cara mereka melihat nilai etika, norma hukum dan sumber harapan sosial yang mempengaruhi perilaku dari individu dan masyarakat. Namun permasalahan dari kenakalan remaja di Kota Padang ini sudah keluar dari koridor falsafah minang yang menjadikan Al-qur'an dan Hadist sebagai pedoman baik dalam agama dan adat. Sehingga dibutuhkan pembenahan dengan perhatian lebih dari masing-masing instansi terkait (individu atau kelompok). Proses pembentukkan karakter melalui peluncuran sebuah program 
peningkatan kependudukan untuk merealisasikan Undang-Undang No. 52 tahun 2009 tentang perkembangan kependudukan dan pembangunan keluarga pasal 48 ayat 1 (b) yang mengatakan bahwa "Peningkatan kualitas remaja dengan pemberian akses informasi, pendidikan, konseling dan pelayanan tentang kehidupan berkeluarga". Maka, untuk mengaplikasikan bunyi pasal tersebut Duta GenRe mempunyai peran sebagai motivator serta fasilitator dalam meningkatkan kualitas dan kuantitas remaja melalui strategi kampanye program GenRe.

Berdasarkan dua pendekatan program GenRe ini peneliti mengambil beberapa lokasi yang menjadi sampel dari penelitian di Kota Padang. Peneliti kemudian melakukan wawancara dari lima titik lokasi sampel penelitian antara lain Dinas Pemberdayaan Perempuan, Perlindungan Anak, Pengendalian Penduduk, dan Keluarga Berencana (DP3AP2KB) Kota Padang, PIK R SMPN 25 Padang (kategori tumbuh), PIK R “Sabai Nan Aluih" SMPN 11 Padang (kategori tegar model), kelompok BKR Anggrek Kec. Padang Selatan (kategori berkembang), kelompok BKR Kampung KB Sinar Gunung IV Kec. Padang Utara (kategori dasar) dengan jumlah 31 orang informan dapat disimpulkan bahwa dengan adanya program ini sedikit banyaknya membantu remaja dalam menafsirkan informasi dan menyelesaikan setiap permasalahan di masa remajanya. Karena program ini menawarkan nuansa ramahnya kehidupan remaja dengan slogan "Dari, oleh, dan untuk remaja".

Berdasarkan pengamatan di lapangan, kegiatan wawancara, dan analisis data yang dimulai dari bulan Oktober-Desember 2018, maka telah didapatkan gambaran mengenai peran Duta Generasi Berencana (GenRe) menjalankan program-program yang telah disusun bersama dalam upaya membantu pemerintah dan orang tua membentuk karakter remaja Kota Padang tepatnya di Provinsi Sumatera Barat yang akan diuraikan sebagai berikut:

\section{Peran Duta Generasi Berencana Kota Padang}

Generasi Berencana merupakan suatu program pemerintah untuk menjadi role model dalam mensosialisasikan kepada remaja. Program GenRe juga efektif dan sesuai dengan Undang-undang Nomor 52 Tahun 2009 tentang perkembangan kependudukan dan pembangunan keluarga. Program GenRe ini sangat membantu dalam persiapan kehidupan remaja apalagi dengan adanya Duta GenRe sebagai penyambung lidah dari kantor DP3AP2KB. Walaupun jika dilihat kembali terkait dengan peran duta GenRe ini memang belum bisa dikatakan maksimal dan optimal dalam pelaksanaan, akan tetapi dinas selalu membina dan mengupayakan mereka untuk bisa memberikan yang terbaik sesuai dengan mottonya yaitu sekali menjabat selamanya menginspirasi. Program GenRe yang kurang berjalan dengan baik dikarena beberapa faktor seperti pendanaan yang kurang tersubsidi kepada para duta yang ingin sosialisasi ke sekolah, cakupan wilayah padang yang luas dan keterbatasan waktu dalam sosialisasi karena tidak cukup hanya 23 kali untuk dapat merubah atau membentuk karakter remaja itu. 
Duta Generasi Berencana merupakan salah satu ikon yang dijadikan role model bagi remaja pada umumnya. Sebuah ikon yang berperan penting dalam pembentukkan karakter remaja untuk menghadapi bonus demografi 2030. Menurut Biddle dan Thomas (dalam Wahyu Agung Saputra, 2018:10) Peran adalah serangkaian rumusan yang membatasi perilaku-perilaku yang diharapkan dari pemegang kedudukan tertentu. Sehingga diperlukannya usaha persuasif yang dilakukan untuk mengajak dan mempengaruhi orang lain dengan memberi wawasan berupa pengetahuan dan nilai-nilai lainnya. Pelaksanaan sosialisasi merupakan kegiatan pemberian akses informasi, pendidikan, konseling dan pelayanan menunjukkan bahwa adanya peran duta GenRe sebagai narahubung sekaligus narasumber dari BKKBN kepada remaja untuk mensosialisasikan dan mempromosikan substansi program GenRe yang dilaksanakan melalui pendekatan dengan dua arah. Pertama, peran duta dalam pengembangan pusat informasi konseling remaja (PIK R) jalur sekolah dan jalur masyarakat. Kedua, peran duta dalam pembinaan kelompok bina keluarga remaja (BKR) di Kecamatan se-Kota Padang.

Program Generasi Berencana dilaksanakan melalui dua pendekatan baik secara langsung dan tidak langsung. Dua pendekatan program GenRe sebagai berikut:

1. Pusat Informasi dan Konseling Remaja (PIK R), PIK R merupakan suatu wadah yang dikelola dari, oleh dan untuk remaja untuk memberikan pelayanan informasi dan konseling terkait kesehatan reproduksi serta kegiatan-kegiatan penunjang lainnya.

2. Kelompok Bina Keluarga Remaja (BKR), BKR merupakan suatu kelompok kegiatan dalam masyarakat yang memiliki remaja usia 10-24 tahun. Kelompok ini dibentuk untuk meningkatkan pengetahuan, sikap dan perilaku orang tua remaja dalam rangka pembinaan tumbuh kembang remaja (BKKBN, 2014).

Selain itu Duta GenRe juga memiliki peran aktif dalam menyebarkan virus-virus positif program GenRe melalui kegiatan pendukung lainnya seperti event peringatan hari besar Islam, nasional dan internasional sehingga peran Duta GenRe dapat selaras dengan jargonnya yaitu "Sekali Menjabat Selamanya Menginspirasi". Secara umum, peran adalah aspek dinamis dari sebuah kedudukan seperti yang dikemukakan oleh Biddle dan Thomas. Peran tidak dapat dipisahkan dengan yang namanya status namun peran bisa disamakan dengan fungsi yang dijalankan. Dalam kehidupan masyarakat, apa yang harus dilakukan oleh seseorang ditentukan oleh peran. Karena ketika seseorang menjalankan hak dan kewajiban mereka sebagai individu maupun makhluk sosial berarti dia sudah menjalankan suatu peranannya. Akan tetapi peran tidak dapat berjalan semaunya melainkan diatur oleh norma-norma serta nilainilai yang berlaku dalam masyarakat. Sehingga, Duta GenRe menjalankan perannya dalam kampanye/sosialisasi harus disesuaikan dengan tugas pokok dan fungsinya.

\section{Pelaksanaan Program Generasi Berencana}


Secara umum BKKBN (Wirdhana, 2014) mengklasifikasikan bahwa program generasi berencana adalah suatu program yang dikembangkan untuk memfasilitasi terwujudnya remaja Indonesia menjadi remaja visioner yaitu remaja yang berkarakter, memahami nilai dan norma, sehat dan terhindar dari resiko Triad KRR (Seksualitas, HIV/AIDS, dan Narkoba serta Zat Adiktif lainnya) yang dikenal dengan sebutan Tegar Remaja. Program ini merupakan strategi pemerintah baik pusat maupun daerah untuk mengatasi permasalahan ledakan penduduk khususnya dikalangan remaja. Pelaksanaan program yang dilaksanakan untuk menjalani kehidupan berkualitas dan berdaya saing tinggi serta memfokuskan kepada pembangunan SDM remaja di Kota Padang yang mempunyai kemampuan tersebut.

Pelaksanaan program generasi berencana dalam pembentukkan karakter melalui 8 fungsi keluarga yang didukung oleh beberapa kelompok kegiatan GenRe dengan tujuan untuk menanamkan nilai-nilai moral. Pada setiap fungsi terdapat nilai dasar yang mesti dipahami dan ditanamkan pada remaja dalam setiap keluarga. Pelaksanaan kegiatan yang dimulai dari proses pemilihan Duta GenRe sekaligus rekruitmen anggota forum GenRe, penguatan keanggotaan melalui pelatihan/pembekalan, pertemuan rutin keanggotaan, kegiatan inti seperti kegiatan penyuluhan/sosialisasi, dan kegiatan pendukung yaitu event peringatan hari-hari besar. Berdasarkan hasil penelitian yang dilakukan oleh peneliti dilapangan terdapat beberapa pelaksanaan program GenRe yang dilakukan oleh instansi terkait bersama dengan Duta GenRe Kota Padang yang tercatat didalam arsip sebagai berikut:

Program Kerja GenRe Kota Padang 2017 - 2018 dan Bentuk Aksi Nyata Kegiatan GenRe

1. Melestarikan budaya daerah "festival siti nurbaya"

2. Project iklan GenRe

3. Kegiatan ramadhan (berbagi bersama) "GenRe berbagi"

4. Peningkatan penggerakan dan pemberdayaan akses remaja dalam pelayanan informasi dan konseling (PIK R/M dan BKR)

5. Peringatan hari besar (nasional dan internasional)

6. Bakti sosial kampung KB

7. Pembinaan dan pelatihan karang taruna Kota Padang

8. Kerjasama dengan forum anak Kota Padang dalam berbagai kegiatan

9. Sosialisasi aksi turun kejalan dan tempat umum

10. Pembinaan dan Pelatihan kader KB

11. Stand peduli remaja

12. Silaturrahmi antar ikatan GenRe

13. Perlombaan antar PIK R/M

14. Pelaksanaan jambore saka kencana Sumber: Dokumentasi DP3AP2KB Kota Padang 2018

Pada hakekatnya yang harus menjadi perhatian oleh Duta GenRe bersama instansi terkait (BKKBN Provinsi Sumatera Barat dan DP3AP2KB Kota Padang) untuk kedapannya agar setiap kegiatan yang dilakukan harus terdokumentasi dengan baik seperti dalam bentuk laporan kegiatan, foto, video, dll yang akan berguna sebagai arsip dan laporan akhir bahan evaluasi instansi. Hal ini juga akan memudahkan jika ada monitoring dan evaluasi dari 
pusat. Selain itu, jika semua kegiatan Duta GenRe terdokumentasi dengan baik akan memudahkan ketika ada lembaga pendidikan, NGO (Non Goverment Organization), atau lembaga swadaya masyarakat yang berkeinginan menjadikan GenRe sebagai objek atau subjek penelitian dan pengabdian masyarakat.

Sehingga dalam pelaksanaannya diperlukan upaya berupa pembuatan dan peningkatan kebijakan untuk menunjang berjalannya program GenRe, 4 (empat) pengelompokkan kebijakan program GenRe (dalam Indra Wirdhana. et. al, 2014:3-4) antara lain:

1. Peningkatan jejaring kemitraan dalam program GenRe.

2. Peningkatan SDM

3. Pengembangan PIK Remaja (Centre of Excellence)

4. Pengembangan kelompok BKR

Tanggapan Masyarakat Terhadap Peran Duta Generasi Berencana dalam Pembentukkan Karakter Remaja di Kota Padang

Tanggapan merupakan pendapat atau reaksi yang diperlihatkan seseorang ketika ia melihat, mendengar dan merasakan sesuatu. Tanggapan juga bisa berupa pertanyaan, tadak hanya persoalan tentang sikap menyetujui ataupun pernyatan tidak menyukai sesuatu. Tanggapan yang diberikan oleh masyarakat dibagi menjadi dua yaitu tanggapan positif dan tanggapan negatif. Kedua kegiatan yang dihasilkan (positif dan negatif) itulah yang dinamakan dengan peran masyarakat. Peran masyarakat yang diperlihatkan dalam berbagai jenis kegiatan yang ada di lingkungan masyarakat. Peran maupun Program
GenRe terutama yang terkait dengan upaya dalam pembentukkan karakter remaja Kota Padang khususnya remaja usia sekolah mendapat tanggapan yang beragam dari masyarakat Kota padang baik tanggapan positif maupun tanggapan negatif. Tanggapan postif yang kemudian diterapkan dengan peran aktif masyarakat dalam setiap kegiatan GenRe. Kegiatan inti maupun kegiatan pendukung dari pelaksanaan program GenRe. Namun, tidak semua masyarakat seperti itu, hal tersebut dikarenakan adanya rasa kurang percaya dengan apa yang akan disampaikan sehingga membuat kurangnya partisipasi masyarakat ketika kegiatan tersebut dilaksanakan.

Berbeda jika hal ini didukung oleh tokoh masyarakat yang dianggap dan dipercaya oleh masyarakat setempat karena kemampuan, wibawa dan kharismatik yang dimilikinya. Yang pada umumnya keberadaan tokoh masyarakat lebih memudahkan dalam penerimaan perubahan. Adanya interaksi bersama dan bantuan dari tokoh masyarakat setempat akan lebih mempermudah duta dalam menjalankan perannya sebagai seorang duta. Rasa kurang percaya masyarakat bisa sedikit demi sedikit diminimalisir oleh keberadaan tokoh masyarakat ini. Sehingga ketidakpercayaan masyarakat karena faktor usia Duta GenRe yang dianggap belum memiliki pengetahuan dan wawasan luas dibandingkan dengan mereka yang telah hidup cukup lama bahkan mempunyai pendidikan yang tinggi. Ini tentunya menjadi tantangan tesendiri bagi Duta GenRe dalam menjalankan perannya untuk menjawab tanggapan negatif yang datang dari masyarakat tersebut. 
Generasi berencana adalah remaja yang memiliki pengetahuan, bersikap dan berperilaku layaknya sebagai seorang remaja, berencana dalam melanjutkan jenjang pendidikan, dapat menyiapkan perencanaan yang matang dalam kehidupan berkeluarga, berkarir dalam pekerjaan secara terencana, dan menikah dengan penuh perencanaan sesuai siklus kesehatan reproduksi yang dianjurkan (Yulianti, Jurusan, \& Publik, 2017). BKKBN juga mengklasifikasikan sasaran dalam Program Generasi Berencana antara lain sebagai berikut:

1. Remaja (10-24 tahun) dan belum menikah

2. Mahasiswa/ mahasiswi belum menikah

3. Keluarga/ Keluarga yang punya remaja

4. Masyarakat peduli remaja

Penelitian terkait Pembentukkan

Karakter Remaja Kota Padang Melalui Program Generasi Berencana (GenRe) ini seperti yang sudah dijelaskan diatas, selain dengan mengadakan observasi lapangan dan wawancara juga menggabungkan antara tiga kelompok jurnal dan/atau artikel penelitian terdahulu yang dijadikan referensi oleh peneliti yaitu pendekatan program melalui pendidikan (PIK-R), pendidikan karakter, dan program generasi berencana. Kemudian ketiga kelompok referensi ini dapat mendeskripsikan secara sederhana maksud tema dari judul penelitian beserta sasaran akhirnya. Sasaran akhirnya adalah pembentukkan karakter remaja melalui pendidikan karakter yang terdapat didalam program Generasi Berencana. Pendidikan karakter adalah sistem yang dilakukan secara berkelanjutan dalam penanaman nilai-nilai karakter kepada remaja. Sehingga nilai karakter yang tertanam didalam jiwa remaja tersebut benar-benar nilai yang dibutuhkan dan diinginkan sesuai dengan Undang-Undang Republik Indonesia Nomor 20 Tahun 2003 tentang Sistem Pendidikan Nasional Pasal 3 menyatakan bahwa pendidikan nasional berfungsi mengembangkan kemampuan dan membentuk karakter serta peradaban bangsa yang bermartabat dalam rangka mencerdaskan kehidupan bangsa.

\section{KESIMPULAN}

Berdasarkan hasil pengamatan dilapangan, kegiatan wawancara dan analisis data yang dilakukan oleh peneliti baik dengan tiga kelompok referensi jurnal, observasi lapangan, dan wawancara bersama informan tentang pembentukkan karakter remaja Kota Padang melalui program Generasi Berencana (GenRe) pada Dinas Pemberdayaan Perempuan, Perlindungan Anak, Pengendalian Penduduk, dan Keluarga Berencana (DP3AP2KB) Kota Padang, dua sekolah menengah pertama, dan dua kelompok bina keluarga remaja di Kota Padang maka diperoleh kesimpulan bahwa peran Duta GenRe dalam upaya pembentukkan karakter Remaja di Kota Padang sudah terlaksana dengan baik. Hanya saja untuk pembenahan dan penyempurna dari program ini perlu adanya proses evaluasi sehingga terjadi pemerataan dalam hal sosialisasi program oleh Duta GenRe. Terutama sosialisasi yang berkaitan dengan program pembentukkan karakter di sekolah seperti sosialisasi bahaya narkoba, pergaulan bebas, life skills, TRIAD KRR (Seksualitas, HIV/AIDS, dan 
Narkoba serta Zat Adiktif lainnya), tawuran antar remaja usia sekolah serta penyakit masyarakat lainnya yang akan berdampak kepada rusaknya kepribadian dan jati diri remaja.

Pelaksanaan program GenRe ini bertujuan untuk mempersiapkan, mengantisipasi dan mencegah perilaku menyimpang remaja di Kota Padang terutama remaja usia sekolah yang akan berakibat pada rusaknya karakter serta jati diri remaja. Dalam rangka pelaksanaan program GenRe peneliti membagi kegiatan dalam lima kelompok kegiatan GenRe yaitu pemilihan Duta GenRe (Rekruitmen anggota), penguatan keanggotaan (pelatihan/pembekalan), pertemuan rutin keanggotaan, kegiatan inti (penyuluhan/sosialisasi), dan kegiatan pendukung (event). Pelaksanaan dari program ini diharapkan dapat membentuk remaja yang visioner yaitu generasi remaja yang berkarakter dengan penuh perencanaan dalam kehidupan (tegar remaja). Secara umum dan pemahaman yang lebih luas program GenRe ini memiliki tujuan khusus untuk membentuk karakter remaja (karakter agama, karakter pancasila, dan karakter nasionalis) bagi generasi bangsa Indonesia.

Sehingga pelaksanaan program GenRe oleh Duta GenRe mendapatkan tanggapan yang beragam dari masyarakat di Kota Padang. Tanggapan positif seperti adanya partisipasi masyarakat pada kegiatan yang dilaksanakan oleh Duta GenRe dalam pembangunan kampung $\mathrm{KB}$ dan tanggapan negatif seperti adanya masyarakat yang memandang sebelah mata Duta GenRe tersebut, karena umur dan pengetahuan mereka yang dianggap masih kurang dalam memiliki pengalaman. Sedangkan peran masyarakat dalam mendukung program GenRe masih belum signifikan ditambah lagi dengan tidak adanya keterlibatan (partisipasi) para tokoh masyarakat dalam setiap kegiatan GenRe. Faktor-faktor penghambat yang juga memberi pengaruh terhadap jalannya pelaksanaan Program GenRe adalah peran duta GenRe, peserta didalam kelompok PIK $\mathrm{R}$ dan BKR, tingkat pendidikan dan usia peserta yang berbeda-beda sehingga harus disesuaikan dengan metode penyampaian materi, tingkat keaktifan atau partisipasi yang berbeda. Namun program ini juga memberikan dampak positif bagi remaja yakni menciptakan wadah untuk dapat berkonsultasi (konseling) bersama teman-teman seusianya. Sehingga sedikit mengurangi ketakutan karena wadah ini bernuansa kehidupan remaja selayaknya. Dan penelitian ini dapat lebih dikembangkan oleh orang-orang yang ahli dibidangnya yaitu bidang keilmuan Bimbingan Konseling.

\section{DAFTAR PUSTAKA}

Andriani, M. (2017). Strategi Kampanye BKKBN DIY Melalui Duta Mahasiswa GenRe Dalam Upaya Mengurangi Masalah Sosial Yang Terjadi Pada Remaja Tahun 2016. Laporan Penelitian. UMY Yogyakarta.

BKKBN. (2014). Pegangan Kader Tentang Bimbingan Keluarga Remaja. Padang: BKKBN Provinsi Sumatera Barat.

Dwiyana, D. (2015). Penyuluhan BKKBN mengenai generasi berencana dan sikap remaja. 
Jurnal Simbolika USU, 1(2), 199210.

ImpianNews. (2019). Selama Oktober 2017 Pelanggaran 746 Di Kota Padang http:/ / www.impiannews.com /2017/11/selama-oktober2017-pelanggaran-746-di.html). Diakses 28 Agustus 2019.

Indahsari, L. I., \& Setyowati, R. N. (2015). Implementasi Ekstrakurikuler Pusat Informasi Dan Konseling Remaja (PIK-R) Dalam Mencegah Kenakalan Remaja Di SMK PGRI Sooko Mojokerto. Kajian Moral dan Kewarganegaraan, 2(3), 651-666.

Maunah, B. (2014). The implementation of character education in the formation of students' holistic personality. Jurnal Pendidikan Karakter, 3(2), 90-101.

Mediastuti, F., \& Setyorini, R. H. (2014). Analisis Pengelolaan Pusat Informasi Dan Konseling The Analysis of Community Based Center for Information and Adolescent Counseling Management in Yogyakarta. MKMI, 80-84.

Purnomo, S. (2014). Krisis Karakter the Crisis of Characters. Jurnal Pembangunan Pendidikan: Fondasi Dan Aplikasi, 2(1), 72-81. Saputra, Wahyu Agung. (2018). Peran Forum Anak Kota Padang Dalam Pemenuhan Hak-hak Anak. Laporan Penelitian. UNP Sumatera Barat.

Undang-Undang No. 20 Tahun 2003 Tentang Sistem Pendidikan Nasional.

Undang-Undang No. 52 Tahun 2009 Tentang Perkembangan Kependudukan dan
Wirdhana,. al. (2014). Pegangan Kader Tentang Bimbingan dan Pembinaan Keluarga Remaja. Perwakilan Badan Kependudukan dan KB Nasional Provinsi Sumatra Barat Tahun 2017.

Yulianti, D., Jurusan, D., \& Publik, A. (2017). Program Generasi Berencana (GenRe) Dalam Rangka Pembangunan Manusia Berkualitas. Analisis Sosial Politik, 1(2), 94-108.

Pembangunan Keluarga. 